\title{
Antioxidant and antimicrobial activities of water-soluble polysaccharide isolated from Balangu seed (Lallemantia royleana) gum
}

\author{
Maryam Sardarodiyan ${ }^{1}$, Akram Arianfar $^{1 *}$, Ali Mohamadi Sani ${ }^{1}$ and Sara Naji-Tabasi ${ }^{2}$
}

\begin{abstract}
Background: Balangu (Lallemantia royleana) belongs to Lamiaceae and is a medicine used in Iranian traditional and folklore medicine in the treatment of various nervous, hepatic, and renal diseases.

Methods: In this study, the influence of molecular weight (MW) was measured on antioxidant and antimicrobial activities of Balangu seed gum fractions. Firstly, Balangu seed gum was fractionated by precipitation method using ethanol on the basis of MW. Two fractions called precipitate (PER) Balangu and supernatant (SUPER) Balangu were obtained as the highest and lowest MW fractions, respectively. Monosaccharide composition was measured by GCMS. The antioxidant activity was measured by two methods, DPPH and FRAP assay. The antibacterial activities were screened against two Gram-positive bacteria (Staphylococcus aureus and Bacillus cereus) and two Gram-negative bacteria (Salmonella enterica and Escherichia coli) by minimum inhibitory and bactericidal concentration (MIC and $\mathrm{MBC})$, disc, and well diffusion method.
\end{abstract}

Results: The results showed that the total phenol contents of Balangu, PER-Balangu, and SUPER-Balangu were 76. $28 \pm 1.41,43.56 \pm 1.72$, and $89.46 \pm 1.38 \mu \mathrm{g}$ gallic acid equivalent/mg sample, respectively. Balangu and its fractions were composed of galactose, glucose, arabinose, rhamnose, and xylose. The $I C_{50}$ values of Balangu, PER-Balangu, SUPER-Balangu, and BHT in DPPH assay were $0.46,0.65,0.38$ and $0.31 \mathrm{mg} / \mathrm{ml}$, respectively. In addition, the reducing power of Balangu, PER-Balangu, SUPER-Balangu, and BHT were 534.92, 431.80, 636.36, and $772.72(\mathrm{mM} \mathrm{Fe} / \mathrm{g})$, respectively. Antibacterial test results showed, that for SUPER-Balangu, the minimum inhibitory concentration and the minimum bactericidal concentration against Staphylococcus were $3.125 \mathrm{mg} / \mathrm{mL}$ and $6.25 \mathrm{mg} / \mathrm{mL}$.

Conclusions: SUPER-Balangu has a great potential as a natural food preservative, antibacterial, and antioxidant agent.

Keywords: Antioxidant activity, Antimicrobial, Balangu seed gum, DPPH, MIC and MBC

\section{Background}

Nature has been a source of medicinal agents for thousands of years, and an impressive number of modern drugs have been isolated from natural sources, many based on their use in traditional medicine. Various medicinal plants have been used for years in daily life to treat disease all over the world. Traditional medicine using plant extracts continues to provide health coverage for over $80 \%$ of the world's population, especially in the developing world (Karakoca et al. 2013).

\footnotetext{
*Correspondence: a_aria_1443@yahoo.com

${ }^{1}$ Young Researchers and Elite Club, Quchan Branch, Islamic Azad University, Quchan, Iran

Full list of author information is available at the end of the article
}

Traditionally, plant compounds are used for treatment of hospital infections in advanced countries. An appropriate method in obviating the common problems of antibiotic side effects is using plant drugs with antimicrobial properties (Golshani and Sharifzadeh 2013). Furthermore, natural antioxidants such as phenolic compounds, flavonoids, and other phytochemicals can act as free radical scavengers. Many reports have indicated that the daily use of foods with high levels of flavonoids may have the potential to decrease the risk of certain cancers, such as colon, breast, and pancreatic cancers (Safaei-Ghomi et al. 2009). These compounds play a crucial role in preventing chronic diseases by retarding the oxidative degradation 
caused by such highly reactive molecules as reactive oxygen species (ROS) (Gharibi et al. 2015).

Antioxidant activity, a common bioactivity of natural-derived polysaccharides, was widely investigated for the prevention and treatment of diseases associated with oxidation damage (Wang et al. 2016). It is widely believed that the antioxidant activity of natural polysaccharides was influenced by raw materials, extraction procedures, and drying methods (Zhu et al. 2012; Zhao et al. 2015).

Balangu (Lallemantia royleana) is a medicinal plant, which is widely grown in different regions of European and Middle Eastern countries especially Turkey, Iran, and India. It is used in a wide range of traditional beverages or industrial products in Iran and Turkey (Razavi and Mohammadi 2011). Seeds of Lallemantia royleana are dark-brown to black in color and smooth. When moistened with water, the seeds become coated with translucent and voluminous mucilage and hydrocolloids. The taste of the moistened seed is bland, soothing, and spicy (Malavya and Dutt 1941; Mohammad Amini and Razavi 2012).

Traditionally, it is a very common practice that local people use indigenous plants to cure infectious diseases. These indigenous plants or plant products or those that are part of food as dietary components are termed as ethnomedicine. Although there are very few reports on the mechanism of action and phytochemistry of these plant-based phytomedicines, traditional knowledge reports that these plants possess potential to cure infectious diseases. Nowadays, these ethnomedicines have been receiving considerable attention by scientist and pharmaceutical research industries with the aim to investigate for more effective substitute (Karsha and Lakshmi 2010; Dogruoz et al. 2008; Samee et al. 2009). Balangu seed contained $45.25 \%$ carbohydrates, $26.60 \%$ protein, $18.27 \%$ oil, $3.63 \%$ ash, and $1.29 \%$ crude fiber, and its length and diameter are $3.148 \mathrm{~mm}$ and $0.720 \mathrm{~mm}$, respectively (Razavi et al. 2016a, 2016b). The Balangu seed is used by Iranian in medicine due to its nutritional and human health virtues, and its seed also is conventionally used in some drinks, like "Tokhme Sharbati" and bread in Iran and Turkey (Razavi et al. 2016a, 2016b).

In some southern parts of Iran, seed powders have been used as a tonic medication and a remedy for psychopath diseases (Safa et al. 2013). L. royleana seeds are reported for the various therapeutics such as treatment of inflammation, respiratory problems, and abscesses (Abdulrasool et al. 2017). Previous studies were focused on its ethno-botany, while medicinal properties of L. royleana are not much evaluated on scientific merits. So far, not a single study has been reported with reference to its antibacterial potential (Mohammad Amini and Razavi 2012; Amiri et al. 2012; Akber et al. 2011).
Monosaccharides composition determined by anion-exchange chromatography (HPAEC) showed the major monosaccharides of Balangu seed gum were in following order: arabinose (37.88\%), galactose (33.54\%), and rhamnose (18.44\%). Trace amounts of xylose $(6.02 \%)$ and glucose $(4.11 \%)$ were also detected in the polysaccharide composition (Razavi et al. 2016a, 2016b).

To the best of our knowledge, no study about the antioxidant and antimicrobial activities was investigated for Balangu and its fractions. Therefore, the objective of this study is to evaluate the antioxidant and antimicrobial activities of water-soluble polysaccharide isolated from Balangu and its fractions.

\section{Methods \\ Materials}

Seeds of Balangu were purchased from a local market in Bojnord, Iran, in May 2018 and cleaned for dust and broken seeds. Ethanol (96\%) was obtained from Pars Alcohol Company (Isfahan, Iran). Other chemicals had analytical grade (Merck Company, Darmstadt, Germany).

\section{Gum extraction}

Balangu seed gum was extracted at optimized conditions (water/seed ratio 59:1, $\mathrm{pH} \mathrm{7}$, temperature $85^{\circ} \mathrm{C}$, and entire extraction time $20 \mathrm{~min}$ ), according to the method described by Mohammad (2007). Segregation of mucilage from the inflated seed was attained through the scraping method. The seeds were crossed through an extractor equipped with a rotating plate which scraped the mucilage layer on the seed surface. The extracted solution was filtered and afterward purified completely by mixing with three volumes of $96 \%$ ethanol to precipitate polysaccharide. The precipitated polysaccharide was dissolved in water and dried overnight in an air-forced laboratory oven at $38^{\circ} \mathrm{C}$. The dried gum was then milled (Magic Bullet, Model 6350M, Korea), sieved (mesh $149 \mu \mathrm{m})$, packed, and kept in cool and dry condition.

\section{Fractionation}

The method of polysaccharide fractionation from Balangu seed gum was set according to Naji-Tabasi et al. (2016) which is on the basis of molecular weight (MW) using ethanol precipitation. For this purpose, Balangu seed gum solution $(0.1 \% \quad w / w)$ was prepared at laboratory temperature for about $24 \mathrm{~h}$ until complete dissolution. Then, various volumes of ethanol $(10-90 \% v / v)$ were added dropwise to the solution at a constant agitation rate on stirrer. The precipitate-Balangu (PER-Balangu) and supernatant-Balangu (SUPER-Balangu) fractions which were known as high- and low-MW fractions were obtained after centrifugation for $10 \mathrm{~min}$ at 12,000 (Sigma, Germany). The fractions were dried then milled (Magic Bullet, Model 6350M, Korea), sieved (mesh $149 \mu \mathrm{m}$ ), packed, and kept at cool and dry condition. 


\section{Determination of total phenolic content}

The total phenolic content extract was determined using the Folin-Ciocalteu method (Hayouni et al. 2007). Here, $100 \mu \mathrm{l}$ of diluted extract $(1000 \mathrm{mg} / \mathrm{l})$ was added to Folin-Ciocalteu reagent $(1 / 10,500 \mu \mathrm{l})$, and then, $1.5-\mathrm{ml}$ sodium carbonate $\left(\mathrm{Na}_{2} \mathrm{CO}_{3}\right)(20 \%)$ was added to the mixture. Then, the tubes were incubated at room temperature for $120 \mathrm{~min}$. The absorbance was read at $760 \mathrm{~nm}$ using UV-VIS spectrophotometer (Cecil CE 1011; UK). The analysis was done in triplicates. Also, the standard curve of gallic acid in methanol $(50-500 \mathrm{mg} / \mathrm{l})$ was prepared (Fig. 1). Total phenolic content was expressed as gallic acid (GA) equivalents ( $\mathrm{mg} \mathrm{GA} / \mathrm{g}$ of dried material).

\section{GC-MS analysis}

Monosaccharide composition was measured by GC-MS according to the technique given by Fathi et al. (2015). The purified sample $(1 \mathrm{ml})$ was hydrolyzed with trifluoroacetic acid $(2 \mathrm{M})$ for $8 \mathrm{~h}$ at $100^{\circ} \mathrm{C}$. The product was recovered using sodium hydride according to the method provided by Wolfrom and Thompson (1951). The acetylation process was performed by adding $\mathrm{Ac}_{2} \mathrm{O}$-Pyridine (1:1 volume ratio) at $25^{\circ} \mathrm{C}$ for $20 \mathrm{~h}$. The solution was dried by nitrogen gas and injected with GC-MS (Agilent, Japan, Tokyo, Technology) after the addition of ethyl acetate. The column used was HP 5923 and nitrogen utilized as the carrier gas (flow rate $1.3 \mathrm{~mL} / \mathrm{min}$ ). The primary temperature of the injection was $280^{\circ} \mathrm{C}$. The temperature of the column was kept at 65 ${ }^{\circ} \mathrm{C}$ for $2 \mathrm{~min}$ and afterwards increased to $300{ }^{\circ} \mathrm{C}$ at $7{ }^{\circ} \mathrm{C} /$ $\mathrm{min}$. The temperature remained constant for $15 \mathrm{~min}$. Identification of pixels based on standards and mass spectrometry was carried out.

\section{Antioxidant activity DPPH radical scavenging assay}

The antioxidant activity extracts were assayed according to the method of Kong et al. (2010). The extracts at different concentrations $(0.1,0.2,0.4,0.6,0.8$, and $1 \mathrm{mg} / \mathrm{ml})$ were prepared. Thus, $1 \mathrm{ml}$ of the sample was mixed with $0.2 \mathrm{ml}$ DPPH in ethanol. After $30 \mathrm{~min}$, the absorbance was measured at $517 \mathrm{~nm}$. The antioxidant activity was calculated using Eq. 1.

$\%$ DPPH scavenging activity $=\frac{\text { Absorbance } 517 \text { of control }- \text { Absorbance }{ }_{517} \text { of sample }}{\text { Absorbance }} \times 100$

Concentration of the sample necessary to scavenge $50 \%$ of the DPPH radicals was calculated using the Bio-Data Fit online software. Butylated hydroxytoluene (BHT) was used as the reference antioxidant.

\section{Reducing power}

The reducing powers of extracts were measured following the method of Malsawmtluangi et al. (2014) using BHT as standard with slight modifications. One milliliter of the sample with various concentrations was mixed with $2 \mathrm{ml}$ of phosphate buffer $(0.2 \mathrm{M}$ and $6.6 \mathrm{pH})$ and $2 \mathrm{ml}$ of $1 \%$ potassium ferricyanide $(w / v)$. The mixture was then incubated at $50^{\circ} \mathrm{C}$ for $20 \mathrm{~min}$, and the reaction was stopped by adding $2 \mathrm{ml}$ of $10 \%$ trichloroacetic acid. The mixture was centrifuged at $3000 \mathrm{~g}$ for $10 \mathrm{~min}$. About $2 \mathrm{ml}$ of the supernatant was mixed with $2 \mathrm{ml}$ of distilled water and $0.4 \mathrm{ml}$ of $0.1 \%$ ferric chloride solution. After $10 \mathrm{~min}$, the absorbance of the resulting solution was measured at $700 \mathrm{~nm}$.

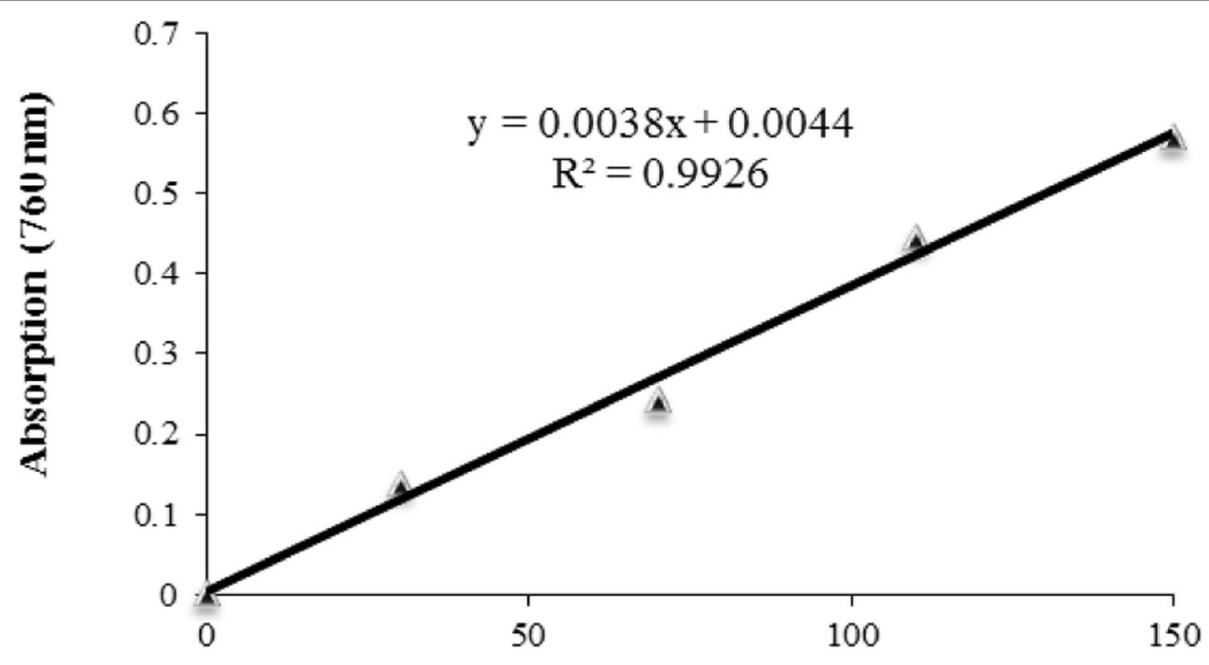

Concentration $(\mu \mathrm{g} / \mathrm{ml})$

Fig. 1 Standard curve of gallic acid 


\section{Organisms and inoculation conditions}

The extracts of Balangu and its fractions were individually tested against four bacterial strains, including Staphylococcus aureus (PTCC 1431), Bacillus cereus (PTCC 1015), Salmonella enterica (PTCC 1709), and Escherichia coli (PTCC 1399) which were obtained from the Persian Type Culture Collection, Iranian Research Organization for Science and Technology (PTCC, Iran). Bacterial strains were cultured overnight at $37^{\circ} \mathrm{C}$ in $\mathrm{MH}$ agar (YesilCeliktas et al. 2007).

\section{Antimicrobial activity}

Antibacterial activity of the Balangu and its fractions was determined by macro-dilution, disc, and well diffusion methods. All tests were performed in three replicates.

\section{Determination of the minimal inhibitory concentration}

Minimum inhibitory concentrations (MIC) were determined by broth macro-dilution method in 96-well plates by Rios et al. (1988) and Duffy and Power (2001) methods.

The initial concentration of the extract was prepared with the aid of bath sonicator with $4 \mathrm{ml}$ solvent and 30\% dimethyl sulphoxide in sterile distilled water and one drop of Tween 80 . One milliliter of diluted extract was infused into macro-plate with $1 \mathrm{ml}$ of sterile Mueller-Hinton broth (MHB; HiMedia, India) and then diluted (50\% with MHB). $0.5 \mathrm{McF}$ arland standard turbidity for microbial suspension equivalent was prepared by suspensions of the growth from brain-heart infusion medium (HiMedia, India). Suspensions were further diluted to obtain a concentration of $10^{7}$ colony-forming units (CFU) per milliliter for the bacteria. Then, $10 \mu \mathrm{l}$ of diluted inoculums was added to each well of macro-plate. The sterility of the medium was also tested in two wells, and gentamicin was used as the positive control for bacterial strains. Plates were incubated for $24 \mathrm{~h}$ at $37^{\circ} \mathrm{C}$ for bacteria. The growth of microorganisms was assessed by TTC (2, 3, 5-triphenyl tetrazolium chloride, Sigma, USA) assay. Briefly, $0.5 \mathrm{ml}$ of TTC $(5 \mathrm{mg} / \mathrm{ml}$; dissolved in sterile water) was added to each well, and the plates were incubated at $37^{\circ} \mathrm{C}$ for bacteria. The results were expressed as the lowest concentration of plant extract that could inhibit any red dye production. Minimum inhibitory concentration (MIC) values were defined as the lowest concentrations of extract that inhibit bacteria after $24 \mathrm{~h}$. All experiments were done in triplicates.

\section{Determination of minimum bactericidal concentrations}

The bactericidal effects of the extract were determined according to the method described by Rios et al. (1988). One hundred microliters of clear dilutions in wells of macro-plate was sub-cultured on the Mueller-Hinton agar plates and subsequently incubated at $37^{\circ} \mathrm{C}$ for $24 \mathrm{~h}$. Minimal bactericidal concentration (MBC) was recorded from the first tube that showed no growth on solid media.

\section{Antimicrobial activity by disc and well diffusion method}

The extract of Balangu and its fractions were tested for antibacterial activity using the disc and well diffusion methods on solid media Mueller-Hinton agar (MHA) plates. The sterile paper discs and wells of $6 \mathrm{~mm}$ diameter were placed on the agar plates with the appropriate media, and the bacteria density was adjusted to approximately $10^{7} \mathrm{CFU} / \mathrm{ml}$. Then, $50 \mu \mathrm{l}$ of diluted extract was applied to test paper disc and well in plates, and the agar plates were further incubated for $24 \mathrm{~h}$ at $37^{\circ} \mathrm{C}$. Finally, the zones of growth inhibition around the discs were measured. Gentamicin and DMSO were used as positive and negative controls, respectively (Firdaus et al. 2011).

\section{Statistical analysis}

The measurements of total phenolic compounds, antioxidant, and antibacterial activities were carried out for three replicates. The results are expressed as mean values \pm standard deviation $(\mathrm{SD})$.

\section{Results and discussion}

Total phenolic content

Folin-Ciocalteu method is a widely used assay for quantitative determination of phenolic compounds (Tawaha et al. 2007; Pourmorad et al. 2006). Based on the data, the standard curve was plotted and the regression was calculated $\left(Y=0.0038 X+0.0044\left(R^{2}=0.9926\right)\right)$ (Fig. 1).

The total phenol contents of Balangu, PER-Balangu, and SUPER-Balangu were determined as $76.28 \pm 1.41$, $43.56 \pm 1.72$, and $89.46 \pm 1.38 \mu \mathrm{g}$ gallic acid equivalent/ mg sample, respectively. Phenolic compounds are secondary plant metabolites that play a key role in the sensory and nutritional quality of fruits, vegetables, and other plants (Ignat et al. 2011).

\section{Monosaccharide composition}

Table 1 shows the monosaccharide composition of Balangu and its fractions.

The polysaccharides of Balangu were composed of glucose $(3.93 \%)$, galactose $(28.31 \%)$, arabinose $(25.64 \%)$, xylose (1.49\%), and rhamnose (1.24\%) (Table 1).

Razavi et al. (2013) found that polysaccharides of Balangu consist of arabinose, galactose, rhamnose, $x y-$ lose, and glucose which were determined as $37.88 \%$, $33.54 \%, 18.44 \%, 6.02 \%$ and $4.11 \%$, respectively. Salehi et al. (2018) showed that the polysaccharides of Balangu are composed of rhamnose (10.7\%), arabinose (29.7\%), and galactose (59.4\%).

Behbahani and Imani Fooladi (2018) found that polysaccharides of Balangu consist of galactose, arabinose, rhamnose, xylose, and glucose which were determined as $36.28 \%, 35.96 \%, 15.18 \%, 7.38 \%$ and $5.20 \%$, respectively.

Farhadi (2017) showed the Balangu was contained of arabinose (7.55\%), rhamnose (5.45\%), mannose (6.47\%), 
Table 1 Monosaccharide composition of the Balangu and its fractions (d.b.\%)

\begin{tabular}{llllll}
\hline Fractions & Glucose & Galactose & Arabinose & Xylose & Rhamnose \\
\hline Balangu & $3.93 \pm 0.51^{\mathrm{a}}$ & $28.31 \pm 0.42^{\mathrm{b}}$ & $25.64 \pm 0.35^{\mathrm{a}}$ & $1.49 \pm 0.03^{\mathrm{c}}$ & $1.24 \pm 0.04^{\mathrm{b}}$ \\
PER-Balangu & $2.32 \pm 0.13^{\mathrm{b}}$ & $32.11 \pm 0.38^{\mathrm{a}}$ & $23.02 \pm 0.02^{\mathrm{b}}$ & $1.93 \pm 0.1^{\mathrm{b}}$ & $0.35 \pm 0.07^{\mathrm{c}}$ \\
SUPER-Balangu & $1.87 \pm 0.17^{\mathrm{c}}$ & $26.20 \pm 0.25^{\mathrm{c}}$ & $18.27 \pm 0.08^{\mathrm{c}}$ & $2.2 \pm 0.17^{\mathrm{a}}$ & $1.72 \pm 0.12^{\mathrm{a}}$ \\
\hline
\end{tabular}

Means in a column followed by different superscript letters are significantly different at $P \leq 0.05$ by Duncan test

fructose $(19.10 \%), \quad$ galactose $(30.03 \%), \quad \alpha$-D-glucose (2.96\%), $\beta$-D-glucose (5.88\%), glucuronic acid (4.70\%), and galacturonic acid (10.18\%). In this research, PER-Balangu was composed of glucose (2.32\%), galactose $(32.11 \%)$, arabinose $(23.02 \%)$, xylose $(1.93 \%)$, and rhamnose (0.35\%). Moreover, SUPER-Balangu was composed of glucose $(1.87 \%)$, galactose $(26.20 \%)$, arabinose (18.27\%), xylose (2.2\%), and rhamnose (1.72\%) (Table 1).

Sharifi-Rad et al. (2015) showed that the major compounds aerial parts of essential oils from L. royleana in Fars Province, Iran, were trans-pinocarvyl acetate (26.0\%), pinocarvone (20.0\%), $\beta$-pinene (1.5\%), (E)- $\beta$-ocimene $(4.1 \%)$, terpinolene $(1.1 \%)$, linalool $(3.4 \%)$, transpinocarveol (1.6\%), 3-thujen-2-one (5.1\%), myrtenal (1.5\%), verbenone (7.1\%), trans-carveol (5.3\%), cis-carveol (3.5\%), pulegone (4.4\%), carvacrol (1.6\%), dihydrocarvyl acetate $(2.5 \%)$, and $\beta$-cubebene $(2.1 \%)$.

\section{Antioxidant activity}

In the present study, antioxidant activity was evaluated by using two different methods, namely, DPPH and FRAP. Results were reported as $\mathrm{IC}_{50}$, which is specified as the amount of antioxidant needed to inhibit $50 \%$ of DPPH free radicals (Liu et al. 2017).

The $\mathrm{IC}_{50}$ value of Balangu, PER-Balangu, SUPER-Balangu, and BHT in DPPH assay were $0.46,0.65,0.38$, and $0.32 \mathrm{mg} /$ $\mathrm{ml}$, respectively (Tables 2 and 3 ).

As shown in Table 2, the DPPH radical scavenging activity followed the order of SUPER-Balangu > Balangu > PER-Balangu. DPPH is a synthetic free radical that shows maximum absorption at $517 \mathrm{~nm}$. Antioxidants can scavenge DPPH free radicals by providing a hydrogen atom and converting them to a colorless product resulting in a reduction in absorbance (Antolovich et al.

Table 2 DPPH free radical scavenging activity in different gum concentrations of Balangu, PER-Balangu, SUPER-Balangu, and BHT

\begin{tabular}{lllll}
\hline $\begin{array}{l}\text { Concentration } \\
(\mathrm{mg} / \mathrm{ml})\end{array}$ & $\begin{array}{l}\text { Balangu } \\
(\%)\end{array}$ & $\begin{array}{l}\text { PER-Balangu } \\
(\%)\end{array}$ & $\begin{array}{l}\text { SUPER-Balangu } \\
(\%)\end{array}$ & $\begin{array}{l}\text { BHT } \\
(\%)\end{array}$ \\
\hline 0.1 & $15.95 \pm 0.11$ & $8.95 \pm 0.32$ & $18.28 \pm 0.17$ & $32.5 \pm 0.21$ \\
0.2 & $25.60 \pm 0.12$ & $15.87 \pm 0.14$ & $34.87 \pm 0.36$ & $41.32 \pm 0.14$ \\
0.4 & $34.85 \pm 0.34$ & $38.23 \pm 0.34$ & $48.23 \pm 0.24$ & $49.97 \pm 0.27$ \\
0.6 & $49.85 \pm 0.57$ & $65.47 \pm 0.10$ & $75.47 \pm 0.30$ & $79.38 \pm 0.44$ \\
0.8 & $57.84 \pm 0.64$ & $69.79 \pm 0.42$ & $79.79 \pm 0.11$ & $88.43 \pm 0.39$ \\
1 & $68.65 \pm 0.35$ & $72.65 \pm 0.12$ & $88.65 \pm 0.41$ & $94.71 \pm 0.74$ \\
\hline
\end{tabular}

2002). Lallemantia royleana seed mucilage total phenolic content and antioxidant activity $\left(\mathrm{IC}_{50}\right)$ were equal to $82.56 \pm 1.6 \mu \mathrm{g} \mathrm{GAE} / \mathrm{mg}$ and $528.54 \pm 0.35 \mu \mathrm{g} / \mathrm{ml}$, respectively (Alizadeh Behbahani and Imani Fooladi 2018).

Different flavonoids and phenolic compounds react with free radical to reduce the degradation of membranes by preventing the reaction between free radicals and phospholipids (Bruneton 1995). They can also be used as antioxidants and in vitro as enzyme inhibitors (Smith et al. 1998). Many phenolics, such as flavonoids, have antioxidant capacities that are much stronger than those of vitamin C and E (Prior and Cao 2000). Many studies on medicinal plants confirm the relation between the antioxidant activity and the presence of polyphenolics content (Ibtissem et al. 2012).

Rice-Evans et al. (1996) reported that phenolic compounds have redox properties which allow them to act as reducing agents, hydrogen donators, and singlet oxygen quenchers. The redox potential of phenolic compound plays an important role in determining the antioxidant capacity (Yen et al. 2004). Norshazila et al. (2010) reported that extracts with high amounts of total phenolic content also showed a high antioxidant activity.

Our study showed that the plant extracts form a strong hydroxyl radical, scavenging DPPH and superoxide anion, and inhibition of yolk lipid peroxidation in a dose-dependent manner as reported earlier (Ganie et al. 2012; Parray et al. 2011) and its possible mechanism may be due to the presence of the alkaloids and phenolic substances that helps to capture lipid peroxidation chain reactions triggered by reactive oxygen species, reduce the lipid peroxidation chain length, and block or slow down the lipid peroxidation (Huang et al. 2006).

Based on the data of reducing power, standard curve was plotted and the regression was calculated $(Y=$ $\left.0.0088 X+0.1052\left(R^{2}=0.9995\right)\right)$ (Fig. 2).

The reducing power of Balangu, PER-Balangu, SUPER-Balangu, and BHT were 534.92, 431.80, 636.36, and $772.72\left(\mathrm{mM} \mathrm{Fe}^{+2} / \mathrm{g}\right)$, respectively (Table 4). The result indicated that the reducing power of SUPER-Balangu was higher than that of Balangu and PER-Balangu.

\begin{tabular}{|c|c|c|c|}
\hline $\begin{array}{l}\text { Balangu } \\
(\mathrm{mg} / \mathrm{ml})\end{array}$ & $\begin{array}{l}\text { PER-Balangu } \\
(\mathrm{mg} / \mathrm{ml})\end{array}$ & $\begin{array}{l}\text { SUPER-Balangu } \\
(\mathrm{mg} / \mathrm{ml})\end{array}$ & $\begin{array}{l}\text { BHT } \\
(\mathrm{mg} / \mathrm{ml})\end{array}$ \\
\hline $0.46 \pm 0.12$ & $0.65 \pm 0.14$ & $0.38 \pm 0.15$ & $0.31 \pm 0.10$ \\
\hline
\end{tabular}




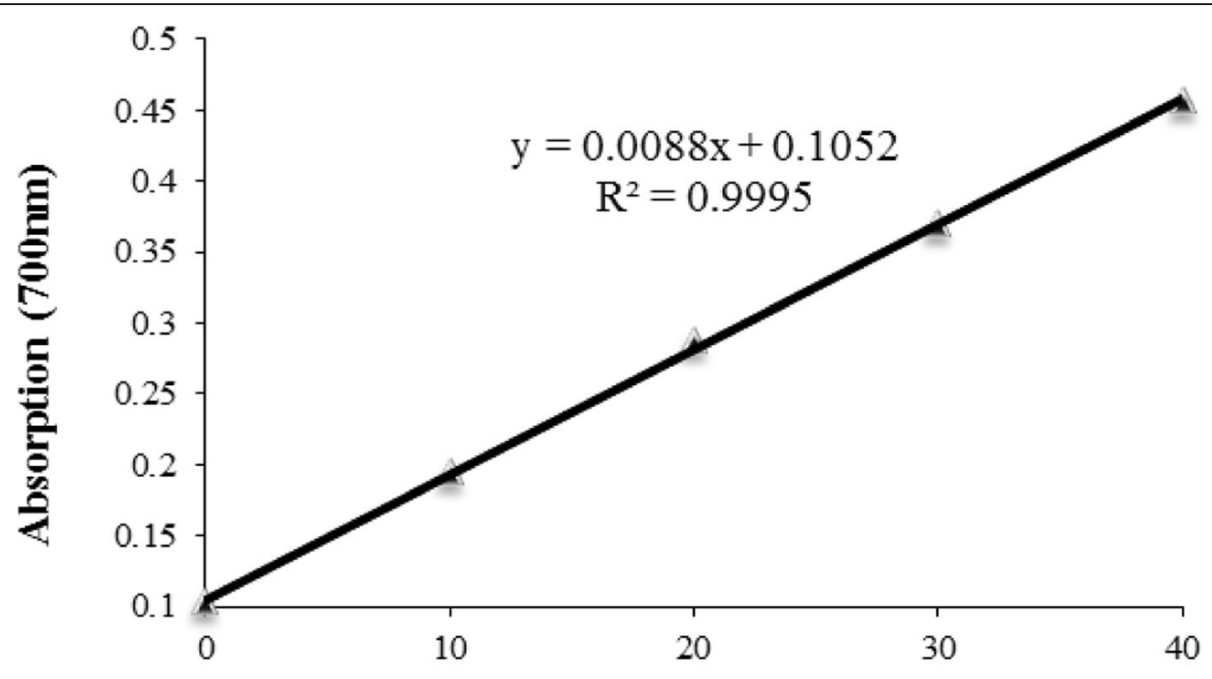

Concentration $(\mu \mathrm{g} / \mathrm{ml})$

Fig. 2 Standard curve of $\mathrm{Fe}^{2+}$ ferric reducing antioxidant power (FRAP) method

Reactive oxygen species (ROS), including oxygen radicals and their reaction products, are known to react with biological molecules, leading to cell and tissue damage. Antioxidant activity is a complex process usually occurring through several mechanisms. Due to its complexity, the evaluation of the antioxidant activity for pure compounds or extracts should be carried out by more than one test method (Aruoma 2003). The lower $\mathrm{IC}_{50}$ value indicates a stronger ability of the extract to act as a DPPH scavenger while the higher $\mathrm{IC}_{50}$ value indicates a lower scavenging activity of the scavengers as more scavengers were required to achieve $50 \%$ scavenging reaction.

Antioxidant activities are known to increase proportionally to the polyphenol content, mainly due to their redox properties (Rasineni et al. 2008). Among the diverse roles of polyphenols, they protect cell constituents against destructive oxidative damage, thus limiting the risk of various degenerative diseases associated with oxidative stress and thus tending to be potent free radical scavengers. Their ability to act as antioxidants is due to their chemical structure and ability to donate/accept electrons, thus delocalizing the unpaired electron within the aromatic structure (Ross and Kasum 2002).

\section{Antibacterial activity}

The results presented in Table 5 and Figs. 3 and 4 are zones of growth inhibition around MIC and MBC of Balangu,

Table 4 Ferric reduction ability of Balangu, PER-Balangu, SUPERBalangu, and BHT (absorbance at $700 \mathrm{~nm}$ )

\begin{tabular}{lccc}
\hline $\begin{array}{l}\text { Balangu } \\
(\mathrm{mM} \mathrm{Fe} / \mathrm{g})\end{array}$ & $\begin{array}{l}\text { PER-Balangu } \\
(\mathrm{mM} \mathrm{Fe} / \mathrm{g})\end{array}$ & $\begin{array}{l}\text { SUPER-Balangu } \\
(\mathrm{mM} \mathrm{Fe} / \mathrm{g})\end{array}$ & $\begin{array}{l}\text { BHT } \\
\left(\mathrm{mM} \mathrm{Fe} \mathrm{H}^{+2} / \mathrm{g}\right)\end{array}$ \\
\hline 534.92 & 438.80 & 636.36 & 772.72 \\
\hline
\end{tabular}

PER-Balangu, and SUPER-Balangu which were evaluated. Antibacterial test results showed that for SUPER-Balangu, the minimum inhibitory concentration, and the minimum bactericidal concentration against Staphylococcus aureus were $3.125 \mathrm{mg} / \mathrm{mL}$ and $6.25 \mathrm{mg} / \mathrm{mL}$.

Table 5 Determination of MIC and MBC of Balangu, PERBalangu, and SUPER-Balangu

\begin{tabular}{|c|c|c|c|}
\hline Technique applied & Test bacteria & $\mathrm{MIC}(\mathrm{mg} / \mathrm{ml})$ & $\mathrm{MBC}(\mathrm{mg} / \mathrm{ml})$ \\
\hline \multirow[t]{4}{*}{ Balangu } & $\begin{array}{l}\text { Staphylococcus } \\
\text { aureus (PTCC 1431) }\end{array}$ & 25 & 25 \\
\hline & $\begin{array}{l}\text { Bacillus cereus } \\
\text { (PTCC 1015) }\end{array}$ & 25 & 25 \\
\hline & $\begin{array}{l}\text { Salmonella enterica } \\
\text { (PTCC 1709) }\end{array}$ & 50 & 50 \\
\hline & $\begin{array}{l}\text { Escherichia coli } \\
\text { (PTCC 1399) }\end{array}$ & 50 & 50 \\
\hline \multirow[t]{4}{*}{ PER-Balangu } & $\begin{array}{l}\text { Staphylococcus } \\
\text { aureus (PTCC 1431) }\end{array}$ & 50 & 50 \\
\hline & $\begin{array}{l}\text { Bacillus cereus } \\
\text { (PTCC 1015) }\end{array}$ & 100 & $>100$ \\
\hline & $\begin{array}{l}\text { Salmonella enterica } \\
\text { (PTCC 1709) }\end{array}$ & 100 & $>100$ \\
\hline & $\begin{array}{l}\text { Escherichia Coli } \\
\text { (PTCC 1399) }\end{array}$ & 100 & $>100$ \\
\hline \multirow[t]{4}{*}{ SUPER-Balangu } & $\begin{array}{l}\text { Staphylococcus } \\
\text { aureus (PTCC 1431) }\end{array}$ & 3.125 & 6.25 \\
\hline & $\begin{array}{l}\text { Bacillus cereus } \\
\text { (PTCC 1015) }\end{array}$ & 12.5 & 12.5 \\
\hline & $\begin{array}{l}\text { Salmonella enterica } \\
\text { (PTCC 1709) }\end{array}$ & 25 & 25 \\
\hline & $\begin{array}{l}\text { Escherichia Coli } \\
\text { (PTCC 1399) }\end{array}$ & 25 & 25 \\
\hline
\end{tabular}



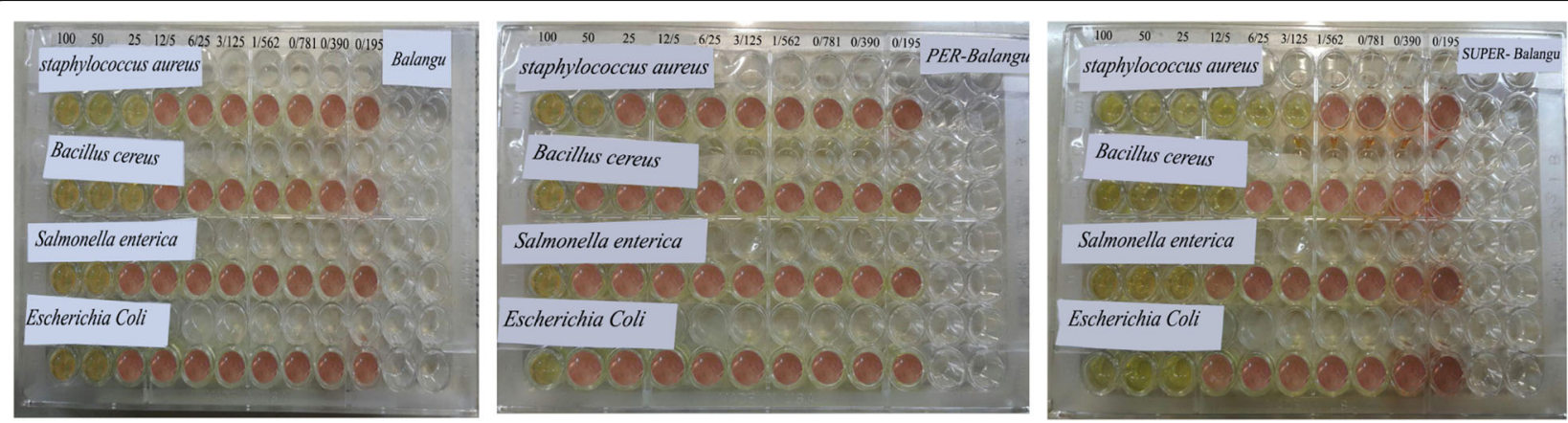

Fig. 3 Determination of MIC of Balangu, PER-Balangu, and SUPER-Balangu

The results showed that plants with high antioxidant properties have high antimicrobial activity too (Fazeli-Nasab et al. 2017), such as the extract of SUPER-Balangu that was the most effective extract on bacteria. In general, phenolic compounds potentially disturb the function of bacterial cell membranes which causes retardation of growth and multiplication of bacteria. Further, phenolic compound is involved in adhesion binding, protein and cell wall binding, enzyme inactivation, and intercalation into the cell wall and/or DNA during inactivation of pathogens (Pereira et al. 2007). Previous studies have suggested that the reactive portion of antimicrobial phenolic compounds may be the free hydroxyl group (Prindle and Wright 1977).

The antibacterial activity of the extracts could be attributed to the high content of phenolic which has been reported to be involved in the inhibition of nucleic acid biosynthesis and metabolic processes (Cushnie and Lamb 2005).

The MIC and MBC values for herbal extracts can vary significantly depending on factors such as chemical composition differences between herbs collected in different countries (differences in the climate, soil composition, age, and vegetative cycle stage) (Masotti et al. 2003), different botanical parts used for extraction (Tilaoui et al.
2015), method of extraction, and differences in strains of microorganisms used (standardized or clinical isolates) (Seukep et al. 2013).

As shown in Tables 6 and 7 and Figs. 5 and 6, antibacterial activities of Balangu, PER-Balangu, and SUPER-Balangu were assessed by well diffusion and disc diffusion methods. Balangu, PER-Balangu, and SUPER-Balangu show antimicrobial activity against Staphylococcus aureus, Bacillus cereus, Salmonella enterica, and Escherichia coli food-borne pathogen (Tables 6 and 7).

As shown in Tables 5, 6, and 7, the highest antimicrobial activity followed the order of SUPER-Balangu > Balangu > PER-Balangu. Therefore, it can be concluded that SUPER-Balangu in appropriate combination can act as an effective food preservative.

The disc and well diffusion methods are dependent on the diffusion ability of the substances, and in these methods, antibacterial property is expressed as diameter $(\mathrm{mm})$ of the zone of inhibition (He et al. 2010).

Aromatic plants have great importance for food, cosmetics, and pharmaceutical industries. They have been used since ancient times, and despite many of them were substituted by synthetic ones, the demand for natural
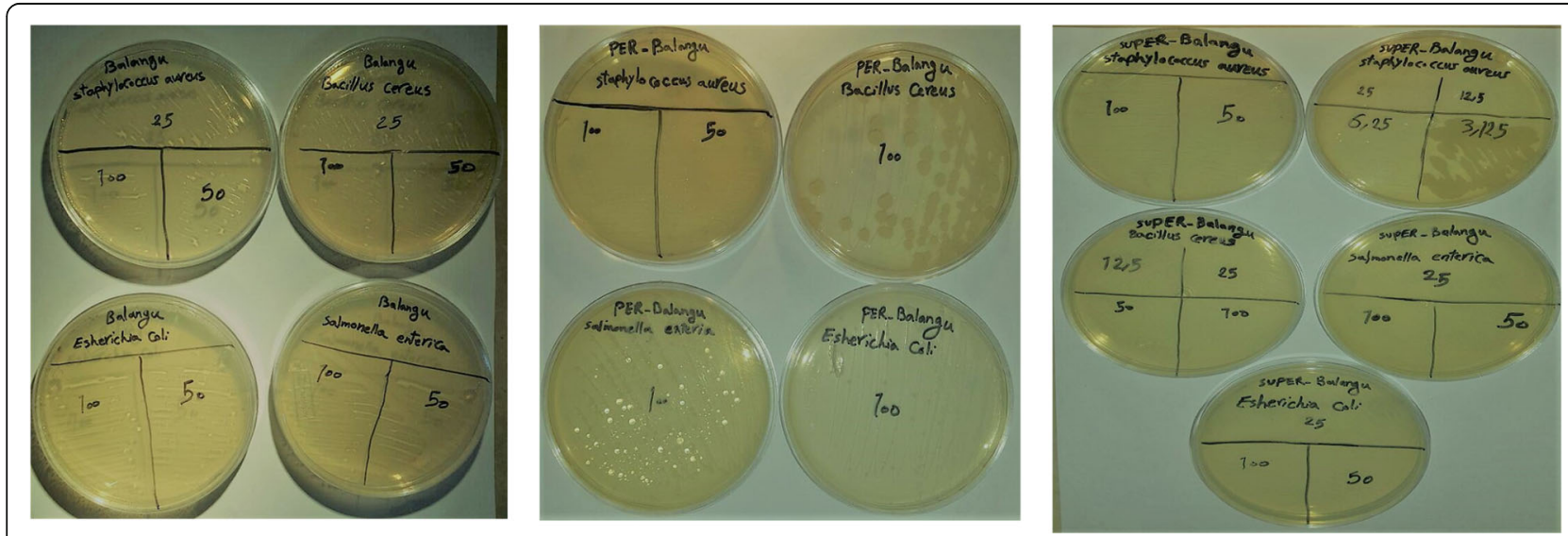

Fig. 4 Determination of MBC of Balangu, PER-Balangu, and SUPER-Balangu 
Table 6 Antibacterial activity of Balangu, PER-Balangu, and SUPER-Balangu assessed by well diffusion method

\begin{tabular}{llllll}
\hline Microorganism & Balangu & PER-Balangu & SUPER-Balangu & Gentamicin & DMSO \\
\hline Staphylococcus aureus (PTCC 1431) & $29 \mathrm{~mm} \pm 0.05$ & $23 \mathrm{~mm} \pm 0.03$ & $34 \mathrm{~mm} \pm 0.04$ & $33 \mathrm{~mm} \pm 0.02$ & $6 \mathrm{~mm} \pm 0.01$ \\
Bacillus cereus (PTCC 1015) & $26 \mathrm{~mm} \pm 0.03$ & $25 \mathrm{~mm} \pm 0.07$ & $33 \mathrm{~mm} \pm 0.08$ & $32 \mathrm{~mm} \pm 0.05$ & $6 \mathrm{~mm} \pm 0.01$ \\
Salmonella enterica (PTCC 1709) & $25 \mathrm{~mm} \pm 0.04$ & $24 \mathrm{~mm} \pm 0.05$ & $29 \mathrm{~mm} \pm 0.06$ & $28 \mathrm{~mm} \pm 0.08$ & $6 \mathrm{~mm} \pm 0.01$ \\
Escherichia Coli (PTCC 1399) & $26 \mathrm{~mm} \pm 0.06$ & $23 \mathrm{~mm} \pm 0.05$ & $28 \mathrm{~mm} \pm 0.02$ & $27 \mathrm{~mm} \pm 0.03$ & $6 \mathrm{~mm} \pm 0.01$ \\
\hline
\end{tabular}

Expressed as the size of the growth inhibition zones $(\mathrm{mm})$ as the average of triplicates

products is increasing (Mickiene et al. 2011). The antimicrobial properties of several naturally occurring compounds have been known for decades. Recently, many plants have received attention as sources of antibiotics (Basile et al. 2000).

Most of the studies on the mechanism of phenolic compounds have focused on their effects on cellular membranes. Phenolic compounds attack cell walls and membranes, thereby affecting their permeability and release of intracellular constituents, but they also interfere with the membrane functions (electron transport, nutrient uptake, protein, nucleic acid synthesis, and enzyme activity). Thus, active phenolic compounds might have several invasive targets which could lead to the inhibition of bacterial pathogens (Bajpai et al. 2008).

Oxygenated monoterpenes are lipophilic in nature and act on the cell membrane which causes substantial morphological damage, resulting in a change in permeability and the release of cellular contents (Moosavy et al. 2008). The Gram-positive strains of bacteria that were tested seemed to be more sensitive to the extracts, which are attributed to the absence of an outer lipopolysaccharide layer in Gram-negative bacteria that provides a resistant barrier (Inouye et al. 2001). The antibacterial activity of flavonoids and polyphenols has been attributed to inhibition of synthesis of RNA and DNA (Arora et al. 2013).

The internal stability of the bacterial cells depends on the interaction between a series of physiological factors, and the disturbance of this stability may determine the bacteria's death or the inhibition of its growth. To provide products, reducing the toxicity risk and at the same time obtaining from a new natural and renewable source becomes a growing and economically viable option. The use of vegetal extracts for antibacterial activity is a consummated fact (Nogueirasa et al. 2014).
Sharifi-Rad et al. (2016) showed L. royleana essential oil had its best inhibitory effect at a MIC of $1 \mathrm{mg} / \mathrm{mL}$, whereas Salvia nemorosa essential oil showed its best inhibitory effects at a higher concentration $(8 \mathrm{mg} / \mathrm{mL})$.

Sharifi-Rad et al. (2015) evaluated L. royleana essential oil against bacteria and fungi by disk diffusion and microbroth dilution method. Results showed that the essential oil have significant inhibition effects on several bacterial and fungi species such as S. aureus, Bacillus subtilis, Klebsiella pneumoniae, Pseudomonas aeruginosa, Candida albicans, and Aspergillus niger.

Viljoen et al. (2002) showed that the two major components of $L$. royleana essential oil are transpinocarvyl acetate $(26.0 \%)$ and pinocarvone (20.0\%). It is assumed that these two components are the main antibacterial agents of $L$. royleana essential oil.

Mahmood et al. (2013) evaluated the antibacterial potential of aqueous and organic extracts (organic solvents are ethanol, methanol, and chloroform) of $L$. royleana seeds against four bacterial strains (Escherichia coli, Enterobacter cloacae, Pseudomonas aeruginosa, and Staphylococcus aureus) by disc diffusion method. Results showed, except aqueous extracts, all organic extracts of L. royleana seeds displayed significant antibacterial activity against all the tested bacteria. The chloroform extract exhibited highest antibacterial activity for all bacterial strains. Therefore, L. royleana seeds possess significant antibacterial potential against $S$. aureus, E. coli, and $E$. cloacae. Mahmood et al. (2013) reported that Gram-positive $S$. aureus was found to be the most sensitive bacterial strain, showing the maximum inhibition zone as compared to other microorganisms in case of all the extracts. Therefore, it is very obvious from results that $L$. royleana seed extracts have significant antibiotic potential against Gram-positive and Gram-negative bacterial strains which is an indication of presence of broad

Table 7 Antibacterial activity of Balangu, PER-Balangu, and SUPER-Balangu assessed by disc diffusion method

\begin{tabular}{llllll}
\hline Microorganism & Balangu & PER-Balangu & SUPER-Balangu & Gentamicin & DMSO \\
\hline Staphylococcus aureus (PTCC 1431) & $29 \mathrm{~mm} \pm 0.02$ & $22 \mathrm{~mm} \pm 0.02$ & $33 \mathrm{~mm} \pm 0.05$ & $31 \mathrm{~mm} \pm 0.08$ & $6 \mathrm{~mm} \pm 0.01$ \\
Bacillus cereus (PTCC 1015) & $28 \mathrm{~mm} \pm 0.06$ & $24 \mathrm{~mm} \pm 0.08$ & $31 \mathrm{~mm} \pm 0.04$ & $29 \mathrm{~mm} \pm 0.05$ & $6 \mathrm{~mm} \pm 0.01$ \\
Salmonella enterica (PTCC 1709) & $27 \mathrm{~mm} \pm 0.03$ & $21 \mathrm{~mm} \pm 0.05$ & $30 \mathrm{~mm} \pm 0.06$ & $28 \mathrm{~mm} \pm 0.09$ & $6 \mathrm{~mm} \pm 0.01$ \\
Escherichia Coli (PTCC 1399) & $25 \mathrm{~mm} \pm 0.07$ & $20 \mathrm{~mm} \pm 0.06$ & $29 \mathrm{~mm} \pm 0.04$ & $28 \mathrm{~mm} \pm 0.07$ & $6 \mathrm{~mm} \pm 0.01$ \\
\hline
\end{tabular}

Expressed as the size of the growth inhibition zones $(\mathrm{mm})$ as the average of triplicates 


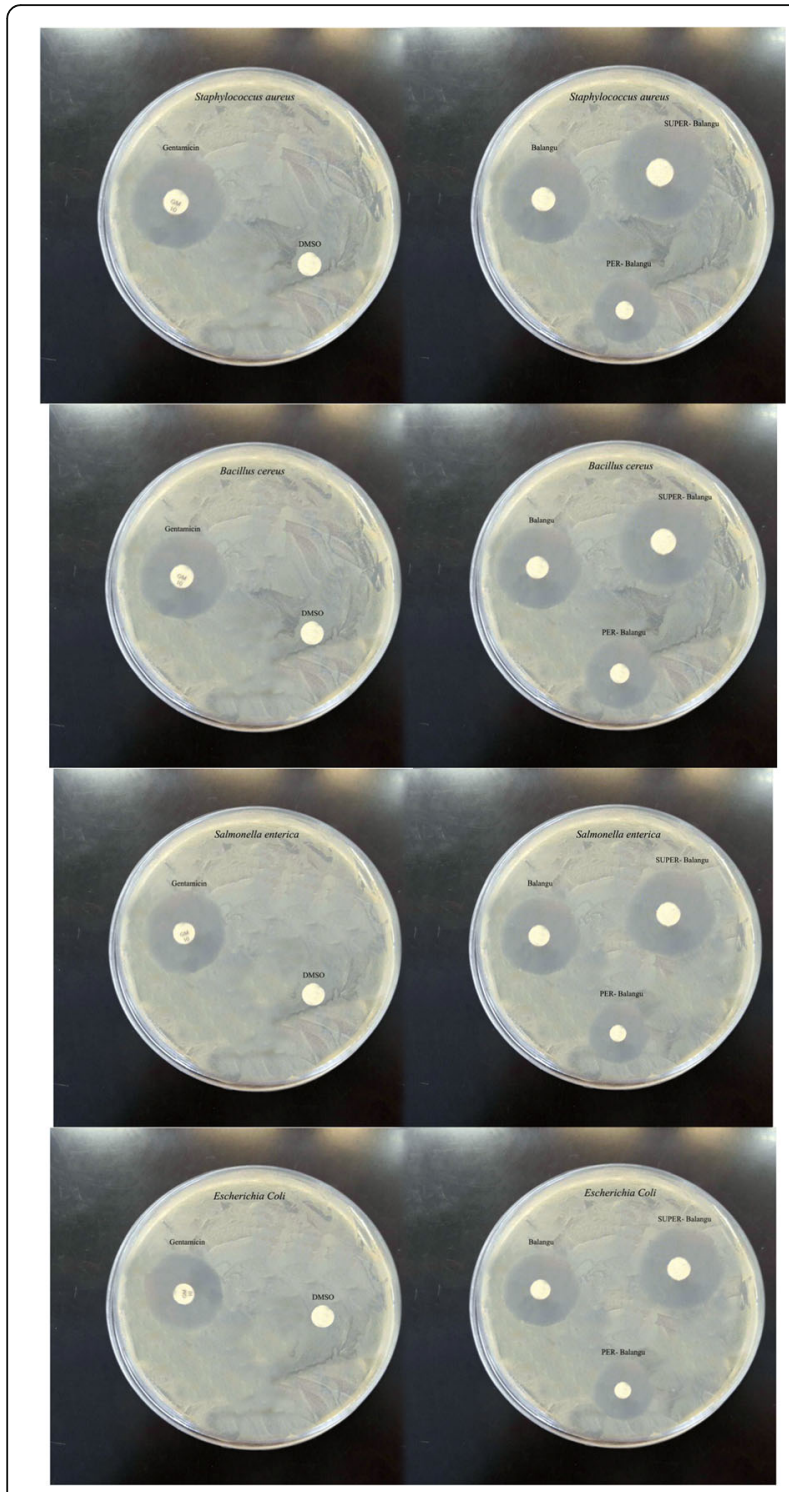

Fig. 5 Antibacterial activity of Balangu, PER-Balangu, and SUPERBalangu were assessed by well-diffusion method

spectrum antibiotic phytoconstituents (Doughari 2006) which impart respective bioactivity to these plant extracts (Gulfraz et al. 2011). Furthermore, still, there is a requirement to determine the active compounds present in the seeds, to classify the compounds that might be more effective against these human pathogenic bacterial strains, and to use a specific formulation of only those compounds in the drug synthesis (Abraham and Thomas 2012).

\section{Conclusion}

The results presented in this study indicated that extracts obtained from the Balangu seed gum possess antioxidant and antibacterial properties. On the basis of the
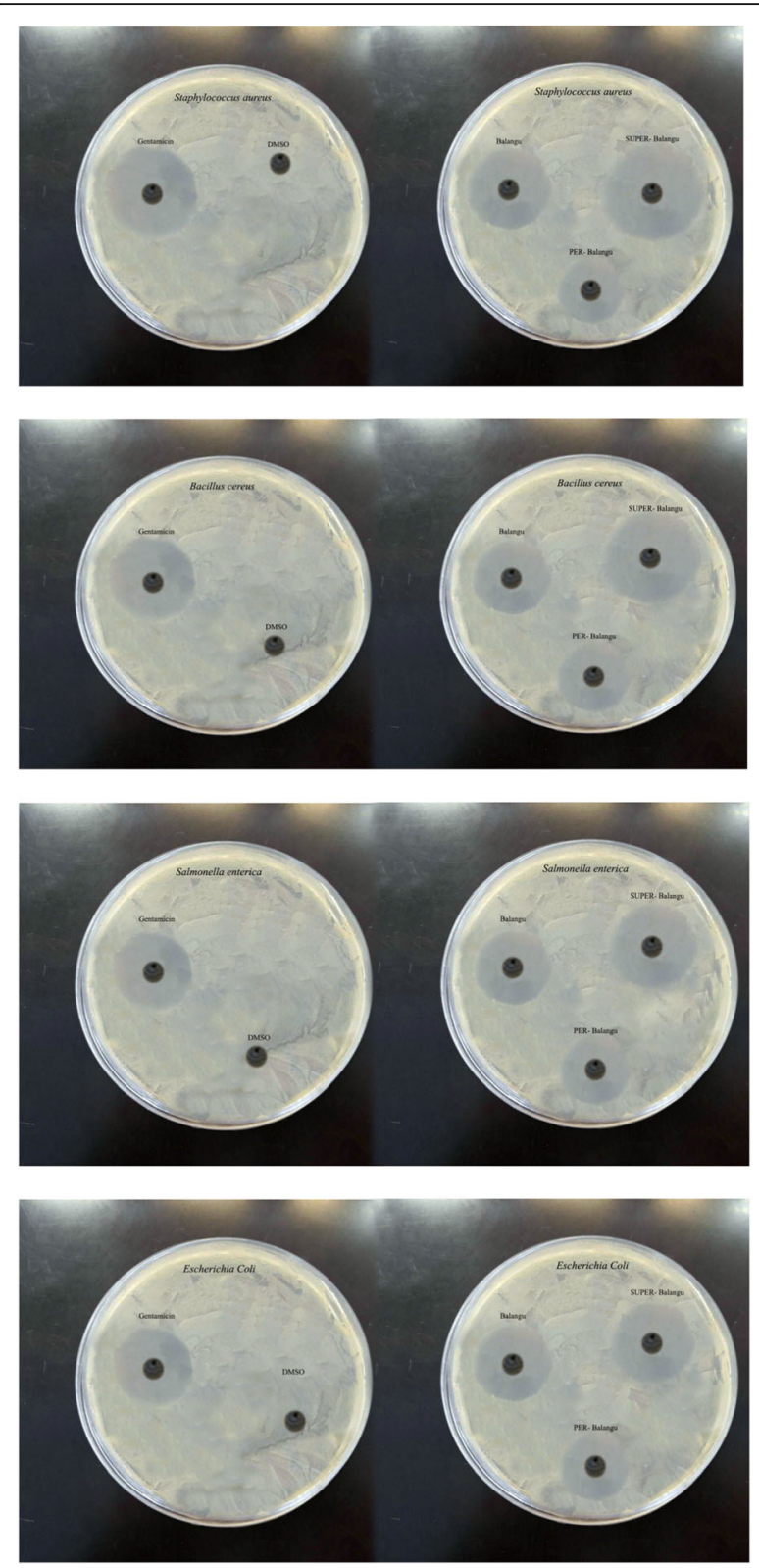

Fig. 6 Antibacterial activity of Balangu, PER-Balangu, and SUPERBalangu assessed by disc diffusion method ${ }^{*}$

experimental results, it can be postulated that the extracts of the Balangu seed gum have the potent antibacterial properties against some representative food-borne pathogens. Specifically, SUPER-Balangu extract was more active against Gram-negative bacteria which indicated the presence of active compounds. The results of this investigation indicated that SUPER-Balangu had a high potential of antioxidant and antibacterial properties. The findings of this study support this view that some medicinal plants are promising sources of potential antioxidant and could be used as preventive agents for some diseases. 


\section{Abbreviations}

BHT: Butylated hydroxytoluene; CFU: Colony-forming units; GA: Gallic acid; L. royleana: Lallemantia royleana; $\mathrm{MBC}$ : Minimum bactericidal concentrations; MHA: Mueller-Hinton agar; MIC: Minimum inhibitory concentrations; MW: Molecular weight; PER-Balangu: Precipitate-Balangu; ROS: Reactive oxygen species; SD: Standard deviation; SUPER-Balangu: Supernatant-Balangu

\section{Acknowledgements}

The authors are grateful to Research Institute of Food Science and Technology, Mashhad, Iran, for providing their facilities.

\section{Funding}

None of the authors did not receive any fund from any person or organization or society.

\section{Availability of data and materials} Not applicable.

\section{Authors' contributions}

MS design and carried out the experiment, and AMS and SNT contributed in framing the article. AA supervised the work. All authors read and approved the final manuscript.

\section{Competing interests}

The authors declare that they have no competing interests.

\section{Publisher's Note}

Springer Nature remains neutral with regard to jurisdictional claims in published maps and institutional affiliations.

\section{Author details}

${ }^{1}$ Young Researchers and Elite Club, Quchan Branch, Islamic Azad University, Quchan, Iran. ${ }^{2}$ Department of Food Nanotechnology, Research Institute of Food Science and Technology (RIFST), PO Box: 91895-157.356, Mashhad, Iran.

\section{Received: 15 January 2019 Accepted: 15 March 2019}

\section{Published online: 18 April 2019}

\section{References}

Abdulrasool AA, Naseer AA, Rahi FA. Application of seed mucilage extracted from Lallemantia royleana as a suspending agent. Iraqi Journal of Pharmaceutical Sciences. 2017;20:8-13.

Abraham J, Thomas TD. Antibacterial activity of medicinal plant Cyclea peltata (Lam) Hooks \& Thoms. Asian Pac J Trop Dis. 2012;2(1):S280-4.

Akber M, Seeraj S, Islam F, Ferdausi D, Ahmed R, Nasrin D, Nahar N, Ahsan S, Jamal F, Rahmatullah M. A survey of medicinal plants used by the traditional medicinal practitioners of Khulna City, Bangladesh. Am Eurasian J Sustain Agric. 2011;5(2):177-95

Alizadeh Behbahani B, Imani Fooladi AA. Shirazi balangu (Lallemantia royleana) seed mucilage: chemical composition, molecular weight, biological activity and its evaluation as edible coating on beefs. Int J Biol Macromol. 2018;114: 882-9.

Amiri MS, Parham J, Mahdi A. An ethnobotanical survey of medicinal plants used by indigenous people in Zangelanlo district. Northeast Iran J Med Plants Res. 2012;6(5):749-53.

Antolovich M, Prenzler P, Patsalides E, et al. Methods for testing antioxidant activity. The Royal Society of Chemistry. 2002;127:183-98.

Arora R, Korekar G, Targais K, Srivastava R, Stobdan T. Combinative effect of Salvia sclarea L., Artemisia annua and Dracocephalum heterophyllum B. essential oils against Salmonella enterica in raw chicken. Medicinal Plants Research. 2013; 7(26):1916-25.

Aruoma Ol. Methodological considerations for characterizing potential antioxidant actions of bioactive components in plant foods. Mutation Research/ Fundamental and Molecular Mechanisms of Mutagenesis. 2003:523:9-20.

Bajpai VK, Dung NT, Kown OJ. Analysis and the potential applications of essential oil and leaf extracts of Silene armeria L.to control food spoilage and foodborne pathogens. Eur Food Res Technol. 2008;227:1613-20.

Basile A, Sorbo S, Giordano S, Ricciardi L, Ferrara S, Montesanoc D, Castaldo Cobianchia R, Vuottob ML, Ferrara L. Antibacterial and allelopathic activity of extract from Castanea sativa leaves. Fitoterapia. 2000;71:110-6.
Behbahani BA, Imani Fooladi AA. Shirazi balangu (Lallemantia royleana) seed mucilage: chemical composition, molecular weight, biological activity and its evaluation as edible coating on beefs. Int J Biol Macromol. 2018; 114:882-9.

Bruneton J. Pharmacognosy, phytochemistiy, medicinal plants. New York: USA Lavoisier Publishing Inc; 1995. p. 265-334.

Cushnie TPT, Lamb AJ. Antimicrobial activity of flavonoids. Int J Antimicrob Agents. 2005;26:343-56.

Dogruoz N, Zeybek Z, Karagoz A. Antibacterial activity of some plant extracts. IUFS J Biol. 2008;67(1):17-21.

Doughari JH. Antimicrobial activity of Tamarindus indica Linn. Trop J Pharm Res. 2006:5:597.

Duffy CF, Power RF. Antioxidant and antimicrobial properties of some Chinese plant extracts. Int J Antimicrob Agents. 2001;17:527-9.

Farhadi N. Structural elucidation of a water-soluble polysaccharide isolated from Balangu shirazi (Lallemantia royleana) seeds. Food Hydrocoll. 2017;72:263-70.

Fathi M, Mohebbi M, Koocheki A. Some physico-chemical properties of Prunus armeniaca L. gum exudates. Int J Biol Macromol. 2015;82:744-50.

Fazeli-Nasab B, Rahnama M, Mazarei A. Correlation between antioxidant activity and antibacterial activity of nine medicinal plant extracts. J Mazandaran Univ Med Sci. 2017;27(149):63-78 Persian.

Firdaus J, Rubina L, Vinod K, et al. Evaluation of antimicrobial activity of plant extracts on antibiotic susceptible and resistant Staphylococcus aureus strains. J Chem Pharm Res. 2011;3(4):777-89.

Ganie SA, Jan A, Muzaffar S, Zargar BA, Hamid R, Zargar MA. Radical scavenging and antibacterial activity of Arnebia benthamii methanol extract. Asia Pac J Trop Med. 2012;5(10):766-72.

Gharibi S, Tabatabaei BES, Saeidi G. Comparison of essential oil composition, flavonoid content and antioxidant activity in eight Achillea species. J Essent Oil Bear Plants. 2015:18:1382-94.

Golshani Z, Sharifzadeh A. Evaluation of antibacterial activity of alcoholic extract of rosemary leaves against pathogenic strains. Zahedan J Res Med Sci. 2013; $16(3): 12-5$

Gulfraz M, Sadiq A, Tariq H, Imran M, Qurashi R. Phytochemical analysis and antibacterial activity of Eruca sativa seeds. Pak J Bot. 2011;43(20):1351-9.

Hayouni EA, Abedrabba M, Bouix M, et al. The effects of solvents and extraction method on the phenolic contents and biological activities in vitro of Tunisian Quercus coccifera L. and Juniperus phoenicea L. fruit extracts. Food Chem. 2007;105:1126-34

He F, Yang $Y$, Yang $G$, et al. Studies on antibacterial activity and antibacterial mechanism of a novel polysaccharide from Streptomyces virginia. Food Control. 2010;21:1257-62.

Huang WS, Lee AR, Yang $\mathrm{CH}$. Antioxidative and anti-inflammatory activities of polyhydroxy flavonoids of Scutellaria baicalensis Georgi. Biosci Biotechnol Biochem. 2006;70:2371-80.

Ibtissem B, Abdelly C, Sfar S. Antioxidant and antibacterial properties of Mesembryanthemum crystallinum and Carpobrotus edulis extracts. Adv Chem Eng Sci. 2012;2:359-65.

Ignat I, Volf I, Popa VI. A critical review of methods for characterisation of polyphenolic compounds in fruits and vegetables. Food Chem. 2011;126:1821-35.

Inouye S, Takizawa T, Yamaguchi H. Antibacterial activity of essential oils and their major constituents against respiratory tract pathogens by gaseous contact. J Antimicrob Chemother. 2001:7:565-73.

Karakoca K, Ozusaglam MA, Cakmak YS, Karaman ES. Antioxidative, antimicrobial and cytotoxic properties of Isatis floribunda Boiss. ex Bornm. Extracts. EXCLI J. 2013;12:150-7.

Karsha PV, Lakshmi OB. Antibacterial activity of black pepper (Piper nigrum Linn.) with special reference to its mode of action on bacteria. Indian J Nat Prod Resour. 2010;1(2):213-5.

Kong F, Zhang M, Liao S, Yu S, Chi J, Wei Z. Antioxidant activity of polysaccharide-enriched fractions extracted from pulp tissue of Litchi Chinensis sonn. Molecules. 2010;15:2152-65.

Liu X, Chen Y, Wu L, Wu X, Huang Y, Liu B. Optimization of polysaccharides extraction from Dictyophora indusiata and determination of its antioxidant activity. Int J Biol Macromol. 2017;103(4):175-81.

Mahmood S, Qasim Hayat M, Sadiq A, Ishtiaq S, Malik S, Ashraf M. Antibacterial activity of Lallemantia royleana (Benth.) indigenous to Pakistan. Afr J Microbiol Res. 2013;7(31):4006-9.

Malavya BK, Dutt S. Chemical examination of the fixed oil derived from the seeds of Lallemantia royleana Benth or Tukhm-I-Malanga. Proc Indiana Acad Sci Sec A. $1941 ; 14(1): 80-4$. 
Malsawmtluangi C, Thanzami K, Lalhlenmawia H, Selvan V, Palanisamy S, Kandasamy R, Pachuau L. Physicochemical characteristics and antioxidant activity of Prunus cerasoides D. Don gum exudates. Int J Biol Macromol. 2014; 69:192-9.

Masotti V, Juteau F, Bessière JM, Viano J. Seasonal and phenological variations of the essential oil from the narrow endemic species Artemisia molinieri and its biological activities. J Agric Food Chem. 2003;51(24):7115-21.

Mickiene R, Ragazinskiene O, Bakutis B. Antimicrobial activity of Mentha arvensis L. and Zingiber officinale R. essential oils. Biologija. 2011;57(2):92-7.

Mohammad AA. Extraction optimization of Balangu seed gum and effect of Balangu seed gum on the rheological and sensory properties of Iranian flat bread. MSc thesis. Iran: Ferdowsi University of Mashhad; 2007.

Mohammad Amini A, Razavi SMA. Dilute solution properties of Balangu (Lallemantia royleana) seed gum: effect of temperature, salt, and sugar. Int J Biol Macromol. 2012;51:235-43.

Moosavy MH, Basti AA, Misaghi A, Salehi TZ, Abbasifar R. Effect of Zataria multiflora Boiss. essential oil and nisin on Salmonella typhimurium and Staphylococcus aureus in a food model system and on the bacterial cell membranes. Food Res Int. 2008:41:1050-7.

Naji-Tabasi S, Razavi SMA, Mohebbi M, Malaekeh-Nikouei B. New studies on basil (Ocimum bacilicum L.) seed gum: part I-Fractionation: physicochemical and surface activity characterization. Food Hydrocoll. 2016; 52: 350-358.

Nogueirasa ER, Medeiros CIM, Oliveira JRDMS, Evangelista AJDJ, Magalhaes MIS, Filho GGDA, Paz AMRD, Pessoa HDLF. "In vitro" antibacterial activity of the hidroalcoholic extract of the Schinus terebinthifolius Raddi Barks. Adv Microbiol. 2014;4:761-5.

Norshazila S, Syed Zahir I, Mustapha Suleiman K, Aisyah MR, Kamarul Rahim K. Antioxidant levels and activities of selected seeds of Malaysian tropical fruits. Malays J Nutr. 2010;16:149-59.

Parray A, Kamili AN, Hamid R, Ganai BA, Mustafa KG, Qadri RA. Phytochemical screening, antifungal and antioxidant activity to Euryale ferox- SALISB. a threatened aquatic plant of Kashmir Himalaya. J Pharm Res. 2011;4(7):2170-4.

Pereira JA, Oliveira I, Sousa A, Valento P, Andrade PB, Ferreira IC, Ferreres F, Bento A, Seabra R, Estevinho L. Walnut (Juglansregia L.) leaves: phenolic compounds, antimicrobial activity and antioxidant potential of different cultivars. Food Chem. 2007:45:2287-95.

Pourmorad F, Hosseinimehr S, Shahabimajd N. Antioxidant activity, phenol and flavonoid contents of some selected Iranian medicinal plants. Afr J Biotechnol. 2006;5:1142-5

Prindle RF, Wright ES. Phenolic compounds. In: Disinfection, sterilization, and preservation. Philadelphia: Lea and Febiger; 1977. p. 219-51.

Prior RL, Cao GJ. Analysis of botanicals and dietary supplements for antioxidant capacity: a review. J AOAC Int. 2000;83(4):950-6.

Rasineni GK, Siddavattam D, Reddy AR. Free radical quenching activity and polyphenols in three species of Coleus. J Med Plant Res. 2008;2:285-91.

Razavi SMA, Alghooneh A, Behrouzian F, Cui SW. Investigation of the interaction between sage seed gum and guar gum: steady and dynamic shear rheology. Food Hydrocoll. 2016a;60:67-76.

Razavi SMA, Cui S, Ding H. Characterization of some physicochemical properties of Balangu (Lallemantia royleana) seed gum. A joint research project between Guelph Food Research Center (GFRC) Canada and Ferdows University of Mashhad (FUM), Iran. 2013.

Razavi SMA, Cui SW, Ding H. Structural and physicochemical characteristics of a novel water-soluble gum from Lallemantia royleana seed. Int J Biol Macromol. 2016b;83:142-51.

Razavi SMA, Mohammadi MT. Influence of different substitution levels of Balangu seed gum on textural characteristics of selected hydrocolloids. Elec J Environ Agric Food Chem. 2011;10(8):2826-37.

Rice-Evans C, Miller NJ, Paganga G. Structure-antioxidant activity relationships of flavonoids and phenolic acids. Free Radic Biol Med. 1996;20:933-56.

Rios JL, Recio MC, Villar A. Screening methods for natural products with antimicrobial activity. J Ethnopharmacol. 1988;23:127-49.

Ross JA, Kasum CM. Dietary flavonoids: bioavailability, metabolic effects, and safety. Annu Rev Nutr. 2002;22:19-34.

Safa O, Soltanipoor MA, Rastegar S, Kazemi M, Nourbakhsh Dehkordi K, Ghannadi A. An ethnobotanical survey on Hormozgan province, Iran. Avicenna J Phytomed. 2013;3:64-81.

Safaei-Ghomi J, Ebrahimabadi AH, Djafari-Bidgoli Z, Batooli H. GC/MS analysis and in vitro antioxidant activity of essential oil and methanol extracts of Thymus caramanicus Jalas and its main constituent carvacrol. Food Chem. 2009;115: 1524-8.
Salehi M, Tabarsa M, Amraie M, Anvari M, Rezaei M, Smith BM. Characterization of rheological and structural properties of a gum from Balangu seeds. Int J Biol Macromol. 2018;117:294-300.

Samee H, Li ZX, Lin H, Khalid J, Guo YC. Anti-allergic effects of ethanol extracts from brown seaweeds. J Zhejiang Univ Sci B. 2009;10(2):147-53.

Seukep JA, Fankam AG, Djeussi DE, Voukeng IK, Tankeo SB, Noumdem JA, Kuete $\mathrm{AH}$, Kuete $\mathrm{V}$. Antibacterial activities of the methanol extracts of seven Cameroonian dietary plants against bacteria expressing MDR phenotypes. Springer Plus. 2013;2:363.

Sharifi-Rad J, Hoseini-Alfatemi SM, Sharifi-Rad M, Setzer WN. Chemical composition, antifungal and antibacterial activities of essential oil from Lallemantia Royleana (Benth. in Wall.) Benth. J Food Safe. 2015;35(1):19-25.

Sharifi-Rad J, Mnayer D, Roointan A, Shahri F, Ayatollahi SAM, Sharifi-Rad M, Molaee N, Sharifi-Rad M. Antibacterial activities of essential oils from Iranian medicinal plants on extended-spectrum $\beta$-lactamase-producing Escherichia coli. Cell Mol Biol. 2016;62(9):75-82.

Smith G, Chesselet F, Van Jaarsveld P, Hartmann EJ, Hammer H, Van Wyk S, Burgoyne B, P Klak C, Kurzweil H. Mesembs of the World Pretoria. Pretoria: Briza Publications; 1998. p. 252-5.

Tawaha K, Alali F, Gharaibeh M, et al. Antioxidant activity and total phenolic content of selected Jordanian species. Food Chem. 2007;104:1372-8.

Tilaoui M, Ait Mouse H, Jaafari A, Zyad A. Comparative phytochemical analysis of essential oils from different biological parts of Artemisia herba alba and their cytotoxic effect on cancer cells. PLoS One. 2015;10(7):e0131799.

Viljoen AM, Klepser ME, Ernst EJ, Keele D, Roling E, van Vuuren S, et al. The composition and antimicrobial activity of the essential oil of the resurrection plant Myrothamnus flabellifolius. S Afr J Bot. 2002;68(1):100-5.

Wang J, Hu S, Nie S, Yu Q, Xie M. Reviews on mechanisms of in vitro antioxidant activity of polysaccharides. Oxid Med Cell Longev. 2016. https://doi.org/10. 1155/2016/5692852.

Yen GC, Duh PD, Su HJ. Antioxidant properties of lotus seed and its effect on DNA damage in human lymphocytes. Food Chem. 2004;89:379-85.

YesilCeliktas O, HamesKocabas EE, Bedir E, Vardar Sukan F, Ozek T, Baser KHC Antimicrobial activities of methanol extracts and essential oils of Rosmarinus officinalis, depending on location and seasonal variations. Food Chem. 2007; 100:553-9.

Zhao Q, Dong B, Chen J, Zhao B, Wang X, Wang L, Zha S, Wang Y, Zhang J, Wang $Y$. Effect of drying methods on physicochemical properties and antioxidant activities of wolfberry (Lycium barbarum) polysaccharide. Carbohydr Polym. 2015;127:176-81.

Zhu H, Sheng K, Yan E, Qiao J, Lv F. Extraction, purification and antibacterial activities of a polysaccharide from spent mushroom substrate. Int J Biol Macromol. 2012;50:840-3.

\section{Submit your manuscript to a SpringerOpen ${ }^{\circ}$ journal and benefit from:}

- Convenient online submission

- Rigorous peer review

- Open access: articles freely available online

- High visibility within the field

- Retaining the copyright to your article

Submit your next manuscript at $>$ springeropen.com 